\title{
Reward System in the Nigerian Political and Public Sector: The Call for a Paradigm Shift in the $21^{\text {st }}$ Century
}

\author{
Michael Sunday Agba (Doctoral Candidate) \\ Department of Public Administration, Federal Polytechnic Idah, Kogi State, Nigeria \\ Email: mikagbaagba@yahoo.co.uk
}

\begin{abstract}
Hassan Achimugu (Doctoral Candidate)
Department of Public Administration, Kogi State University, Anyigba, Kogi State, Nigeria

Email: hassanachimugu@ yahoo.com

Chukwurah, D.C.J. (Doctoral Candidate)

Department of Public Admin. Nnamdi Azikiwe University, Awka, Anambra State, Nigeria

Joy Uyo Agboni (Doctoral Candidate)

Department of Public Administration, Kogi State University, Anyigba,, Kogi State, Nigeria

Email: Joyata80@yahoo.com
\end{abstract}

Accepted: August 15, 2012 Published: September 05, 2012

Doi:10.5296/ijld.v2i5.2343 URL: http://dx.doi.org/10.5296/ijld.v2i5.2343

\begin{abstract}
Reward system defined in terms of remunerations, salaries, wages, allowances, and fringe benefits constitute a dominant feature of political and public institutions in developed and developing countries. Nigeria as a social formation operates a reward system where civil servants and political office holders are remunerated through salaries, fringe benefits and allowances for performing legislative, executive and administrative functions. This paper is an attempt at examining political and other public servants salaries and allowances within the backdrop of its implications on human resource management, productivity and sustainable development of the country. The paper argues that because reward systems are highly skewed in favor of the political class in comparison to salaries and allowances in other sectors of the economy, Nigerian politicians have turned democratic elections into investment areas and opportunities and battle fields where money, private armies and thugs are employed to create enabling environments that guarantee returns on investments and accelerated access to primitive accumulation of wealth. Given the inequality in the Nigerian reward system between the political and other classes in the country, the paper argues that a paradigm shift aimed at the restructuralization of the reward system and the fight against corruption are inevitable for human capital development, productivity enhancement and sustainable development of the country in the $21^{\text {st }}$ century.
\end{abstract}

Keywords: Political Office Holders; Academic Staff; Salaries and Allowances Productivity; Sustainable Development; Civil Servants and Nigerian. 


\section{Introduction}

Political, university academic staff and civil servants remunerations have become a subject of national debate and concern following its consequential effects on productivity, human capital and sustainable development in Nigeria. This paper is an attempt to lend voice to this debate and make prescriptions as a way out of the conundrum.

For purpose of exposition, the paper is decomposed into sections. The paper begins with a section on introduction, followed by statistics on reward systems in Nigerian political and public sectors. In section three, the implications of the inequalities in Nigerian reward systems on human resource management and sustainable development are examined. The paper ends with recommendations and concluding remarks.

\section{Statistics On Reward Systems In The Nigerian Political And Public Sectors}

Statistics on reward systems in Nigeria are highly skewed in favor of the political class. As Uba Sani acknowledges, legislators' pay is shocking (Ibrahim, 2010:25). This is a collaborative remark to the revelation made by Lamido Sanusi, Governor of the Central Bank of Nigeria to the effects that members of the National Assembly consume 25\% of the country's annual budget. Ezeoke (2010:56) in an article demonstrated that federal legislators are feeding fat on the masses. As he puts it, a comparative analysis of the income of federal legislators and those of their counterparts in other parts of the world points to insensitivity and financial recklessness on the part of Nigerian lawmakers. The table below shows in comparative terms that the Nigerian democratic institution is not only expensive but an easiest means to wealth accumulation.

Table 1. Annual Earnings of Some US Politicians

$\begin{array}{lrc}\text { Position } & \text { US Dollars } & \text { Naira Equivalent } \\ \text { President (US) } & 400,000 & \text { N60m } \\ \text { V. President (US) } & 227,300 & 34.1 \mathrm{~m} \\ \text { Speaker of the House (US) } & 223,500 & 33.5 \mathrm{~m} \\ \text { Majority Leader (Senate) } & 193,400 & 29.1 \mathrm{~m} \\ \text { Minority Leader (Senate) } & 193,400 & 29.1 \mathrm{~m} \\ \text { Other Senators } & 174,400 & 26.1 \mathrm{~m} \\ \text { Majority Leader (Representative) } 193,400 & 29.1 \mathrm{~m} \\ \text { Minority Leader (Representative) } 193,400 & 29.1 \mathrm{~m} \\ \text { Cabinet Secretary } & 193,400 & 29.1 \mathrm{~m}\end{array}$

Source: Tell Magazine, December, 20, 2010, P.56

\section{What Government Officials Earn in Nigeria}

Table 2

Cumulative Gross Salaries and Allowances

\begin{tabular}{|l|l|}
\hline President & N11,949,997 \\
\hline Vice President & N10,307,344.80 \\
\hline
\end{tabular}

Chief Justice of the Federation 


\begin{tabular}{|l|l|}
\hline Basic Salary & $\mathrm{N} 3,363,977$ \\
\hline Accommodation & $175 \%$ of basic salary \\
\hline Furniture & $\begin{array}{l}150 \% \text { of basic } \\
\text { salary }\end{array}$ \\
\hline $\begin{array}{l}\text { Motor Vehicle } \\
\text { Loan }\end{array}$ & $250 \%$ of basic salary \\
\hline Fuelling & $50 \%$ of basic salary \\
\hline Hardship & $25 \%$ of basic salary \\
\hline Robe & $25 \%$ of basic salary \\
\hline Newspaper & $15 \%$ of basic salary \\
\hline
\end{tabular}

National Assembly

\begin{tabular}{|c|c|c|}
\hline Senate President & \multicolumn{2}{|c|}{$\begin{array}{ll}\mathrm{N} 2,484,242.50 \quad \text { ( } & \text { Basic } \\
\text { Salary }) & \end{array}$} \\
\hline Deputy Senate President & \multicolumn{2}{|c|}{$\begin{array}{l}\text { N2,309,166.75 } \quad(\quad \text { Basic } \\
\text { Salary) }\end{array}$} \\
\hline $\begin{array}{l}\text { Speaker of the House of } \\
\text { Reps. }\end{array}$ & \multicolumn{2}{|c|}{ N2,477,110 ( Basic Salary) } \\
\hline Deputy Speaker & \multicolumn{2}{|c|}{ N2,026,400 ( Basic Salary) } \\
\hline Other Senators each earns & \multicolumn{2}{|c|}{ N2,026,400 ( Basic Salary) } \\
\hline House of Reps member & \multicolumn{2}{|c|}{$\begin{array}{l}\text { N1,985,212.50 ( Basic } \\
\text { Salary) }\end{array}$} \\
\hline App & \multirow{2}{*}{$\begin{array}{l}\text { Senators } \\
150 \% \text { of } \\
\text { basic salary }\end{array}$} & Representatives \\
\hline Accor & & $\begin{array}{l}150 \% \text { of basic } \\
\text { salary }\end{array}$ \\
\hline Furn & $\begin{array}{l}150 \% \text { of } \\
\text { basic salary }\end{array}$ & $\begin{array}{l}150 \% \text { of basic } \\
\text { salary }\end{array}$ \\
\hline Car Loan & $\begin{array}{l}250 \% \text { of } \\
\text { basic salary }\end{array}$ & $\begin{array}{l}250 \% \text { of basic } \\
\text { salary }\end{array}$ \\
\hline Personal Ass & $\begin{array}{l}25 \% \text { of basic } \\
\text { salary }\end{array}$ & $\begin{array}{l}25 \% \text { of basic } \\
\text { salary }\end{array}$ \\
\hline $\begin{array}{l}\text { Duty Tour } \\
\text { Allowance(per night }\end{array}$ & $\mathrm{N} 23000.00$ & $\mathrm{~N} 21000.00$ \\
\hline Estacodes & 600USD & 550USD \\
\hline Domestic staff & $\begin{array}{l}50 \% \text { of basic } \\
\text { salary }\end{array}$ & $\begin{array}{l}50 \% \text { of basic } \\
\text { salary }\end{array}$ \\
\hline Entertainment & $\begin{array}{l}20 \% \text { of basic } \\
\text { salary }\end{array}$ & $\begin{array}{l}20 \% \text { of basic } \\
\text { salary }\end{array}$ \\
\hline Utilities & $\begin{array}{l}25 \% \text { of basic } \\
\text { salary }\end{array}$ & $\begin{array}{l}10 \% \text { of basic } \\
\text { salary }\end{array}$ \\
\hline Recess & $\begin{array}{l}10 \% \text { of basic } \\
\text { salary }\end{array}$ & $\begin{array}{l}10 \% \text { of basic } \\
\text { salary }\end{array}$ \\
\hline Newspapers/periodicals & $\begin{array}{l}10 \% \text { of basic } \\
\text { salary }\end{array}$ & $\begin{array}{l}10 \% \text { of basic } \\
\text { salary }\end{array}$ \\
\hline Responsibility & $\begin{array}{l}10-5 \% \text { of } \\
\text { basic salary }\end{array}$ & $\begin{array}{l}20 \% \text { of basic } \\
\text { salary }\end{array}$ \\
\hline
\end{tabular}




\begin{tabular}{|l|l|l|}
\hline Constituency & $\begin{array}{l}125 \% \text { of } \\
\text { basic salary }\end{array}$ & $\begin{array}{l}75 \% \text { of basic } \\
\text { salary }\end{array}$ \\
\hline Severance Gratuity & $\begin{array}{l}300 \% \text { of } \\
\text { basic salary }\end{array}$ & $\begin{array}{l}300 \% \text { of basic } \\
\text { salary }\end{array}$ \\
\hline
\end{tabular}

Minister

\begin{tabular}{|l|l|}
\hline Basic Salary & \\
\hline Allowances & $\mathrm{N} 3,039,600.00$ \\
\hline Accommodation & $\mathrm{N} 3,039,600.00$ \\
\hline Furniture & $\mathrm{N} 5,066,000.00$ \\
\hline Motor Vehicle Loan & $\mathrm{N} 1,013,200.00$ \\
\hline Motor Vehicle Fuelling & $\mathrm{N} 1,013,200.00$ \\
\hline Domestic staff & $\mathrm{N} 506,600.00$ \\
\hline Utility & $\mathrm{N} 202,640.00$ \\
\hline Leave & $\mathrm{N} 405,280.00$ \\
\hline Monitoring & $\mathrm{N} 35,000.00$ \\
\hline $\begin{array}{l}\text { Duty tour allowance per } \\
\text { day overseas }\end{array}$ & $800 \mathrm{USD}$ \\
\hline $\begin{array}{l}\text { Estacodes for at } \\
\text { travels per day }\end{array}$ & $\mathrm{N} 6,079,200.00$ \\
\hline $\begin{array}{l}\text { Severance allowances } \\
\text { the completion of tenure }\end{array}$ \\
\hline
\end{tabular}

Breakdown of Basic Salaries of Government officials in Benue State

\begin{tabular}{|l|l|l|}
\hline Governor & $\mathrm{N} 1,200,000.00$ & \\
\hline Deputy Governor & $\mathrm{N} 1000000.00$ & \\
\hline $\begin{array}{l}\text { Secretary to the state } \\
\text { government }\end{array}$ & $\mathrm{N} 700,000.00$ & \\
\hline $\begin{array}{l}\text { Speaker of the State } \\
\text { House of Assembly }\end{array}$ & $\mathrm{N} 500,000.00$ & $\begin{array}{l}\text { No } \\
\text { Personnel }\end{array}$ \\
\hline & & 18 \\
\hline Commissioner & $\mathrm{N} 500,325$ per person \\
\hline Senior Special Asst & $\mathrm{N} 153,000.00$ per person & 34 \\
\hline Senior Assistants & $\mathrm{N} 141,000.00$ per person & 22 \\
\hline Personal Assistants & $\mathrm{N} 138,000.00$ per person & 28 \\
\hline Chief of staff & $\mathrm{N} 368,058.6$ per person & 3 \\
\hline Chief press secretary & $\mathrm{N} 265,022.00$ per person & 5 \\
\hline Legislative Aides & $\mathrm{N} 58,000.00$ per person & 54 \\
\hline $\begin{array}{c}\text { House } \\
\text { Assembly }\end{array}$ & $\mathrm{N} 350,000.00$ per person & 30 \\
\hline Special advisers & $\mathrm{N} 450,175.8$ per person & 21 \\
\hline
\end{tabular}

Source: Sunday Mirror, $29^{\text {Th }}$ January, 2012, p.5 
The table above shows why Nigerian form of democracy has become a means through which a few politicians in power feed fat on the masses at the expense of the development of the country. It also justifies the call by Nigerians for a paradigm shift to review downward the wages and allowances of politicians to reflect the prevailing socio-economic reality of a country of about 140 million people and yet less than 10 millions could boast of having a decent living. To say the least, politicians at the federal, state and local government levels are the highest paid public office holders; consequently, politics in Nigeria has become prebendalistic and wrongly perceived as a commercial and business venture where millions of naira are invested in the electoral process and billions of naira is reaped as profit (Agba, Coker, Agba, 2010). Personal interests of politicians, their supporters and political god fathers seem to be the utmost pursuit of the vast majority of political office holders throughout the years spent in office.

The chairman, Board of Trustees of the People Democratic Party (PDP) once observed that nobody knows in details how much it costs the country to maintain a senator but it is more than N250 millions. Consequently, he advised that we should now:

...talk truly to ourselves seriously. We can't continue to have a National Assembly that is consuming a disproportional part of our resources and then expect that we would be able to make progress. They pass budget that can't be implemented because it has to be beefed up to satisfy their whims and caprices. Even what the ministries did not ask for they put it (Alao, 2010:26).

The call for a paradigm shift in the reward system in Nigeria is long overdue. According to the Nigerian Labour Congress (2009), between 2006 and 2007, workers' salaries increased by less than 40 percent while those of political offices increased by over 800 percent. There are other more revealing statistics on salaries and allowances of politicians in Nigeria. According to Ezeoke (2010:56), the senate president in Nigeria takes N250 million naira quarterly or 83.33 million naira per month while his deputy earns 50 million naira per month, amounting to N150 million naira per quarter. With that, the Senate President and his deputy earn in four months, six times what the UK Prime Minister earns in a year. As Ezeoke (2010) further notes, in the United States, apart from the moderate salary that political office holders earn, offices are also not duplicated, as in the case in Nigeria. The vice president is the same person as the senate president. With that, the cost of running offices is reduced. This implies that the cost of democratic governance in Nigeria is exorbitant with good percentage of public funds not recurrent expenditure for political office holders.

For a country whose economy is essentially monoculture, an irritable jumbo pay package for National Assembly members is the least expected. It is estimated that it will cost the country at least N338 billion in tax payers' money to keep the 469 members of the seventh National Assembly in office for the next four years (Chukwulaka, Ojo, and Anumihe, 2011). The above amount as they further analyzed, did not factor in the deferential pays and other perquisites that go to the principal officers of the two chambers of the federal legislature. It does not also include expenses incurred on duty tours and estacodes. It is also silent on the unverifiable, lump sums that come from oversight functions' and lobbying.

The jumbo pay of politicians at federal, state and local government levels when compared with what a professor earns annually as table 2 reveals shows the inequality and discrimination in wage distribution in the country. Furthermore, the minimum wage of the federal civil service is 
put at N7500 although it was raised to 18000 with serious doubt as to it effective implementation in the federal and state civil service. It will be recalled that the Nigerian Labour Congress and trade unions in the country were at loggerhead with the federal and state governments over a minimum wage of 18,000 naira which the federal government claimed to have signed into law in error. This development raises fundamental issues which cast doubt on the commitment of the government to the welfare of civil servants as a means of motivating the work-force for higher productivity. Summarizing the consequence of this, Alao (2010:26) notes:

Annually, lecturers and teachers of educational institutions go on strikes which seem to have become a compulsory ritual in the nations educational system, which itself has become a defected child. Not to talk of health workers who down-tool leaving countless lives unattended to, all for one reason, lack of adequate and commensurate pay for their toil.

A critical analysis of wages and allowances of political office holders will reveal a huge wage discrimination and disparity between what they earn and the N18000.00 (monthly) national minimum wage which the federal government and some state government are yet to implement. By the estimate of the minimum wage of N18000.00 the least paid government worker in Nigeria earns N234, 000.00 per annum and if the $13^{\text {th }}$ month extra pay is added, it means he or she earns a meager of 0.13 per cent of a senator's salary. Following the postulations of Abraham Maslow hierarchy theory of needs, it means the monthly salary of a least paid government worker in Nigeria is physiologically "demotivating" and under this condition, service render will be epileptic and poor.

It is important to ask whether the salaries and allowances received by federal legislators and other politicians in government are justifiable. According to Suleiman (2010:57), considering the number of hours the legislators spends in the chambers, many would find it hard to justify the huge resources the nation expends on them. There are three legislative days in a week -Thursday, Wednesday and Thursday. Both chambers rarely sit on Fridays unless there is a bill that requires urgent consideration. Yet sittings in the upper and lower houses last just a few hours before they are adjourned. However, the jumbo pay of politicians may be justified on the grounds that politicians have developmental commitment to their constituencies which can be executed the jumbo pay they received. The issue is that how many of these politicians are actually affecting positively their constituencies.

\section{Implications of Political and Public Sector Reward Systems on Nigerian Socio-economic Development}

Nigerian reward systems raise a number of questions that have political, socio-economic, developmental, productivity and human resource management implications in the country. Firstly, Nigeria's nascent democracy and the associated jumbo pay package has become a watershed for improving the economic conditions of politicians in power and have further widen the gap between the political elite and the masses. This implication is glaring when one compares what the country spends to maintain a senator and the mass poverty in the country. For instance, statistics on poverty in Nigeria are frightening and not encouraging. A country with about $70 \%$ of its population living or navigating below poverty line of two dollars per day cannot afford to continue to spend an average of 25 percent of its total annual overhead cost of the federal budget on few persons, who serve as legislators or political office holders. It is in the light of this that, the Central Bank Governor cautioned that should this continue, Nigeria 
may never compete with the emerging economies in Asia. The 2010 recurrent budget of the Federal Government stood at N500 billion while the recurrent expenditure of the National Assembly, NASS, stood at N136.2 billion, amounting to about 25 percent of the recurrent budget (Manuaka, 2010:55). This shows the profligacy of reward system in Nigerian political system following the emergence of politicians with prebendalistic minds and not the mind to serve. A paradigm shift that sees politics as service to the people and servant leadership is inescapably required.

Some of the monies expended in the name of Jumbo pay for legislators, advisers, house of assembly members and a host of others can be converted to create jobs that will address the unemployment problems in the country. Data on unemployment shows that only one out of every ten Nigerian graduate is gainfully employed; showing that something is wrong with the system. A country of about 140 million people, less than 10 million can boast of having a decent living. The expectation of many before May 1999 is that, democratic governance will usher in dividends that will translate to the overall development of Nigeria. Unfortunately, 12 years after democratic resurgence in Nigeria, the situation has not changed. As Uba Sani notes in an interview with Sunday Tribune, 15 August, 2010:

The level of poverty in the country has worsened and the same goes for unemployment in the country. The problem is that the people who are currently there do not give the people adequate representation.

Explaining the challenge further Uba Sani, a onetime special adviser on public affairs to former President Olusegun Obasanjo observed that in most of the 70 wards he visited during his campaign for the seat of Kaduna Central

Senatorial District, the people complained that they have not seen their senator since he was elected. As he maintained aptly, you cannot solve the problems of the people if they do not have access to you. Thus, he remarked that:

If I got there, I certainly will be one of the people who will canvass that such salary (jumbo pay package) should be stopped because when you are there, you should be able to work for the interest of the people. I do not see how the people from your constituency will have problems of unemployment, poverty, disease and you go to the National Assembly and collect such salary. It is unfortunate.

The jumbo pay package to politicians also has human resource management and productivity implications. It will be recalled that the battle for the N18000.00 minimum wage for public sector workers in Nigeria has been ongoing. Generally, government has been finding it difficult to accept and start immediate payment of the minimum wage of N18, 000.00 which we cannot say is a living wage for Nigerian civil servants across the country. For government to pay millions of naira to a senator and yet find it difficult to commerce immediate payment of a minimum wage of N18, 000.00 to its workers shows the value the government places on its workforce largely consisting of civil servants. It is generally believed that an organization that does not pay its workers well should not expect high performance from them especially in Nigeria. This is because they will be demoralized, and their attention will be shifted to survival strategies and business. For instance, most Nigerian local government workers in attempt to survive, engage in series of survival strategies like farming, petty trading, farming, okada business, etc thereby increasing the incidence of absenteeism and negligence of official duties. 
In other words, commitment, devotion and satisfactory job performance cannot be harvested from Nigerian workers in the absence of an enhanced pay and other productivity enhancement variables like regular power supply, exemplary leadership style, meritocracy, infrastructural facilities, team spirit, etc.

Agba; Coker and Agba (2010), have argued that politically, the financial attractiveness of elective positions in the Nigeria could be considered as the root cause of political thuggery and electoral malpractices in the country. Okei-Odumakin cited in Sunday Mirror of $29^{\text {th }}$ January, 2012 aptly observed that, the unintended consequence of the financial rascality in Nigerian political office holders is the murderous ferocity with which aspirants to elective posts jostle to be there. And the spoils that are innate to these offices make them opportunities to die for. Below could be considered as other political implications of jumbo pay package of political office holders:

(i) Scramble for political posts whether qualified or not. In most cases if not all, when the unqualified person emerges, it affects his performance in delivery the dividends of democracy expected from him by the masses;

(ii) Internal squabbles in viable political parties which may hit up the spade of insecurity in the country;

(iii) political motivated assassinations and party crises;

(iv) absence of public accountability and abuse of power and raising tide of political bureaucratic corruption;

(v) abuse of the legal process to secure victory in electoral tribunals;

(vi) relegating to the background the rule of law;

(vii) installation of unpopular governments, thus threatening the legitimacy of the democratic process;

(viii) political prostitution, decamping of party members and multiplication of unviable political parties to avoid death and squabbles; and

(ix) employment of thugs and private armies through excess income coming from jumbo pay package.

\section{Concluding Remarks}

To curb the adverse implications of wage discriminations as depicted in the above disquisition, the need for a paradigm shift is long overdue. Civil servants should be paid wages that reflect the prevailing economic realities and this should be backed up by the provision of facilities that are important in enhancing workers' job performance. Some of these facilities are: regular electric power supply, good roads, good office accommodation, medical facility, security of lives and property, training of staff, etc. On the part of politicians, it is important to begin to conceive politics as service to the people and not an investment area for quick money making or primitive wealth accumulation. The salaries and allowances of political office holders should be reviewed downward to conserve resources for other developmental purposes.

\section{References}

Agba, M.S., Coker, M.A., Agba, A.M.O. (2010). "Political Thuggery and Democratic Dividends in Nigeria". International Journal of Public Administration, 33 (4): 192-199. 
Alao, M. (2010). “A Legislator's N250 Million and What it Can Achieve". Sunday Tribune, 15 August

Chukwulaka, M., Ojo J. and Anumihe, I. (2011).” Jumbo Pay: Lawmakers to Earn N338.6 Billion”, Daily Sun ,June 03,

Ezeoke, J. (2010). "Feeding Fat on the Masses". Tell, December, pp. 56

http://www.nigeriamasterweb.com/paperfrmes.httml

Ibrahim, H. (2010). "Legislators' Pay is Shocking". Sunday Tribune, 15 August; P.25. Uba Sani was a pro-democracy activist before joining the government of ex-President Olusegun Obasanjos' as a Special Adviser on Public Affairs.

"Nigeria's Democracy: Expensive, Outrageous Salary, Perks", Sunday Mirror, 29 January, 2012

NLC (2009). "Nigerian Labour Congress Demand for the Review of National Minimum and General Wage". http: //www.nicng.org/minimum\%20wage.pdf. 